\title{
III MIĘDZYNARODOWE SYMPOZJUM NAUKOWE PT. „POLITICA SENZA RELIGIONE? LAICITÀ DELLO STATO, APPARTENENZE RELIGIOSE E ORDINAMENTO GIURIDICO" 9-11.09.2007 Lugano (Szwajcaria)
}

Zakład Międzynarodowy Prawa kanonicznego i Prawa porównawczego religii zorganizował w dniach 9-11 września 2007 roku III Międzynarodowe sympozjum naukowe pt.: „Czy polityka bez religii?” Na konferencję przybyli prelegenci z całego świata, m.in. z Uniwersytetu Gregoriańskiego, z Uniwersytetu w Bambergu, Strasburgu, Leuven, Jerozolimy, Nowego Jorku, Moskwy, Madrytu, Monako. Program sympozjum zawierał propozycje prelekcji plenarnych, jak też dyskusję panelową w grupach i drugiego dnia plenarną.

Gości przybyłych na sympozjum powitał ks. prof. dr Libero Gerosa - rektor Wydziału Teologicznego w Lugano (FTL) i dyrektor Zakładu Prawa porównawczego religii (DiReCom). W swoim wystąpieniu nawiązał do tematu konferencji. Relacja polityka - religia, mówił ks. Rektor, wymaga właściwego uporządkowania w rzeczywistości multikulturowej Europy. Tak jak polityka ma swoją przestrzeń, którą wykorzystuje do realizacji celów politycznych, tak powinno uwzględniać się stosowne miejsce dla religii. Obie rzeczywistości w odniesieniu do podstawowych wartości ludzkich, jak respektowanie praw człowieka, sprawiedliwy podział dóbr materialnych, stosowanie zasady solidarności, szacunek dla życia, rodziny, środowiska naturalnego, stanowią gwarancję ładu wewnętrznego i bezpieczeństwa zewnętrznego.

Pierwszej debacie przewodniczył prof. dr Silvio Ferrari z Uniwersytetu w Mediolanie, który dokonując wprowadzenia do wystąpień poszczególnych prelegentów powiedział: „Polityka bez etyki lub bez kultury z pewnością byłaby niemożliwa, bez religii natomiast rzeczywistość wygląda inaczej. Ataki grup terrorystycznych przyczyniają się do pierwszej reakcji, sugerującej wręcz wyłączenie religii z poziomu jej funkcjonowania na płaszczyźnie polityki, co w konsekwencji być może przyczyniłoby się do przeżywania w bardziej harmonijny sposób czasu w życiu społeczeństw”. Ksiądz bp dr Rino Fisichella - rektor Papieskiego Uniwersytetu Laterańskiego w Rzymie, w swojej prelekcji, której treść nawiązywała do problemu wiodącego konferencji: „Laickość państwa, przynależności religijne i porządek prawny: perspektywa filozoficzno-teologiczna" podkreślił, że błędną jest ta interpretacja relacji polityka - religia, która odnosi się do religii chrześcijańskiej Kościoła katolickiego. Katolicyzm nie jest 
nieprzyjacielem wspólnoty demokratycznej - mówił ks. bp Fisichella. Życie Kościoła, które pozostaje w służbie Bogu i człowiekowi przebiega w strukturach konkretnych grup etnicznych i państw. Należy wyróżnić zakres semantyczny pojęć laickość państwa, udział religii i porządek prawny. W swojej treści pojęcia te nie wykluczają się, ale się wyróżniają. Właściwe ich odniesienie do struktur życia jednostki w państwie pozwala na komplementarne ich zastosowanie. Dojrzała demokracja powinna uwzględnić prawdę religii. W demokratycznej i pluralistycznej społeczności europejskiej nie powinno być aktów związanych $\mathrm{z}$ eliminowaniem z życia społecznego wartości i symboli religijnych $\mathrm{w}$ imię rzekomej wolności i tolerancji, co w rzeczywistości prowadzi do dyskryminacji ludzi wierzących. Profesor dr Carlo Cardia - profesor Uniwersytetu z Rzymu, zauważył, że odpowiedzialna postawa za wiarę w życiu wielu chrześcijan, pełniących funkcje publiczne, w multikulturowej Europie, wielokrotnie jest powodem ich zakłopotania i strachu, podczas gdy wyznawcy islamu przeżywają ich religijność wręcz z dumą. I chociaż wystąpienie profesora nie miało charakteru roszczeniowego względem innych religii i ich relacji z państwem, to jednak było pewną formą apelu, aby model przyszłościowy Europy demokratycznej przyczyniał się do ożywiania troski w relacji do wyznawców wszystkich religii chroniącej tożsamości indywidualnej swoich wyznawców. To tożsamość i pluralizm religijno-polityczny pozwoli na ukształtowanie nowej, pokojowej i demokratycznej Europy. Powyższe wystąpienia stały się punktem odniesienia do merytorycznych dyskusji w grupach językowych: dwie w języku włoskim, dwie w języku niemieckim i jedna w języku angielskim. Do przewodniczenia zostali zaproszeni: prof. dr Ottavio de Bertolis z Uniwersytetu Gregoriańskiego w Rzymie i prof. dr Roberta Aluffi Beck-Peccoz z Uniwersytetu w Turynie; prof. dr Rinaldo Bertolino z Uniwersytetu w Turynie i prof. dr Massimo Jassoni z Uniwersytetu w Modenie; prof. dr Alfred Herold z Uniwersytetu w Bambergu i prof. dr Jean Werckmeister z Uniwersytetu w Strasburgu; prof. dr Sabine Demel z Uniwersytetu w Regensburgu i prof. dr Peter Krämer z Uniwersytetu w Trier; prof. dr Rik Torfs z Uniwersytetu w Leuven i prof. dr Marco Ventura z Uniwersytetu w Sienie.

W drugim dniu o prelekcje w sesji plenarnej zostali poproszeni: prof. dr Giuseppe dalla Torre - rektor Uniwersytetu katolickiego w Rzymie, prof. dr Yedidia Z. Stern z Uniwersytetu Bar-Ilan z Jeruzalem i prof. dr Balsam Tibi z Uniwersytetu z Göttingen i Nowego Jorku. Prelegenci wskazali na potrzebę uwzględniania inności tych trzech kategorii, które określają temat konferencji tj.: „Laickość państwa, przynależności religijne i porządek prawny”. Zdaniem prelegentów laickość, która pojawiła się w tradycji francuskiej, charakteryzowała wrogość w stosunku do zjawiska religijnego. Dlatego też zrodziła się potrzeba uwolnienia państwa laickiego i społeczeństwa od religii i przesunięcia całej sfery przeżywania religii w obszar prywatności. Tradycja społeczeństwa amery- 
kańskiego inaczej interpretuje zagadnienie laickości. Religia stanowi niezbędny czynnik dla pluralistycznej zbiorowości społeczeństwa i kształtuje tożsamość zbiorową multikulturowej społeczności. Niemiecki model natomiast sprowadza ideę laickości państwa do uwolnienia spod ingerencji Kościoła, w duchu weimarskich założeń. Wypada zatem, aby wolne laickie państwo w konfrontacji $\mathrm{z}$ propozycją religii zachowało otwartość i zapewniło naturalny klimat w przeżywaniu wątku religijnego poszczególnych jednostek kierując się zapewnieniem komfortu sprzyjającego wolnemu funkcjonowaniu jednostek w pluralistycznej społeczności. Poważny dialog religii i świata laickiego polityki wymaga zmiany paradygmatu, który postulowałby nieuchronność zaniku świata religijnego. Jakiekolwiek wydania fundamentalizmu, czy to na gruncie religii czy laicyzmu, będą zawsze prowokacją i źródłem konfliktu. Następnie odbyły się debaty w grupach, którym przewodniczyli: prof. dr Manuel Aeroba Conde z Uniwersytetu Laterańskiego w Rzymie i prof. dr Alessandro Ferrari z Uniwersytetu w Como; prof. dr Rinaldo Bertolino z Uniwersytetu w Turynie i prof. dr Romeo Astorri z Uniwersytetu katolickiego w Mediolanie; prof. dr Alfred Herold z Uniwersytetu w Bambergu i prof. dr Ludger Müller z Uniwersytetu w Wiedniu; prof. dr Sabine Demel z Uniwersytetu w Regensburgu i prof. dr Francis Messner z Uniwersytetu w Strasburgu; prof. dr Rik Torfs z Uniwersytetu w Leuven i prof. dr Sophie van Bijsterveld z Uniwersytetu w Tilburgu.

Sesja popołudniowa miała charakter debaty plenarnej i sprowadzała się do zauważenia z jednej strony czysto laickiej kultury, która religię w multikulturowej Europie wypycha poza ramy życia publicznego i dyskursu politycznego, kwestionując jej publiczną rolę, z drugiej dowolność, relatywizm, indyferentyzm jako kategorię w ogóle wycofującą $\mathrm{z}$ dyskursu publicznego, w imię laickości państwa, poszukiwanie prawdy. Uczestnikami debaty byli: prof. dr Piero Martinoli - prezydent Uniwersytetu Szwajcarii włoskiej, dr Janne Haaland-Matláry - profesor polityki międzynarodowej Uniwersytetu w Oslo, dr Mario Scialoja wiceprezydent światowej organizacji muzułmańskiej, dr Rolf Bloch - prezydent federacji wspólnoty żydowskiej w Szwajcarii i inni goście.

W trzecim dniu obrad w sesji plenarnej wystąpili: prof. dr Christoph Winzeler z Uniwersytetu we Fryburgu i prof. dr Vsevolod Chaplin - wiceprezydent departamentu współpracy z zagranicą Patriarchatu z Moskwy. Sesji przewodniczył prof. dr Gianfranco Girlanda - rektor Uniwersytetu Gregoriańskiego w Rzymie. Dyskusje w grupach językowych prowadzili: prof. dr Adriano Fabris z Uniwersytetu w Pizie i prof. dr Vincenzo Pacillo z Uniwersytetu w Modenie; prof. dr Antonio Neri z Wydziału Teologicznego w Lugano i prof. dr Georgio Feliciani z Uniwersytetu katolickiego w Mediolanie; prof. dr Alfred Herold z Uniwersytetu w Bambergu i prof. dr Arnd Uhle z Uniwersytetu w Monaco; prof. dr Sabine Demel z Uniwersytetu w Regensburgu i prof. dr Stephen Haering z Uniwersytetu w Monaco oraz prof. dr Rik Torfs z Uniwersytetu w Leuven 
i prof. dr Iván Ibán z Uniwersytetu w Madrycie. Podsumowania trzydniowej konferencji dokonał prof. dr Libero Gerosa - rektor Wydziału Teologicznego w Lugano, stwierdzając, że źródło problemu nie powinno koncentrować się na separacji polityki od religii, ale na współpracy instytucjonalnej, która będzie zapewniała ludziom wolność w przeżywaniu przez nich tożsamości osobowej. Pluralistyczne społeczeństwo Europy powinno stworzyć przestrzeń dla każdej jednostki, rozumiejąc potrzebę jej funkcjonowania w konkretnej rzeczywistości materialnej, tworzonej przez strukturę społeczno-polityczno-ekonomiczną państwa, ale też i jej realizacji w porządku duchowym odzwierciedlającym godność każdej osoby: mężczyzny i kobiety. Fundamentalizmy tworzące relacje polityka - religia zarówno w wymiarze konfesyjnym, jak i laickim są niewskazane.

Ks. Andrzej Proniewski Uniwersytet w Białymstoku 